Diabetologia 10, 131-134 (1974)

(C) by Springer-Verlag 1974

\title{
Relationship between Plasma Corticosterone and the Development of Ketoacidosis in the Alloxan Diabetic Rat*
}

\author{
M. L'age, W. Fechner, J. Langholz and H. Salzmann \\ Abteilung für Endokrinologie, Medizinische Klinik und Poliklinik, Klinikum Steglitz, Freie Universität Berlin \\ Federal Republik of Germany \\ Received: September 10, 1973, and in revised form: November 26, 1973
}

\begin{abstract}
Summary. Withholding of insulin therapy in alloxan diabetic rats results in a steady increase of plasma corticosterone, which is associated with a decrease in $\mathrm{pH}$ and bicarbonate and with an increase in plasma FFA and ketone bodies. Adrenalectomy prevents the development of ketoacidosis after withholding insulin therapy, whereas stimulation of the adrenal cortex accelerates the development of diabetic ketoacidosis. In insulin deficiency a
\end{abstract}

stress signal produces significantly higher corticosterone levels when compared with normal rats. It is concluded that glucocorticoids are involved in the development of ketoacidosis in the insulin deficient rat.

Key words: Alloxan diabetes, rat, plasma corticosterone, FFA, ketone bodies, ketoacidosis.
High plasma cortisol levels are found in severe diabetic ketoacidosis in children [1] and in diabetic coma or precoma in adults [2,3]. However, in these studies it was not determined whether the increase in plasma cortisol is a consequence of a "metabolic stress" or precedes the severe metabolic disturbances.

In this study we have recorded plasma corticosterone levels and several metabolic parameters during the development of diabetic ketoacidosis in the rat, produced by withholding insulin therapy from alloxanized rats [4] maintained in good condition by insulin treatment for several weeks.

\section{Materials and Methods}

Male Sprague-Dawley rats were kept $3-5$ per cage, with tap water and a commercial laboratory chow (Altromin ${ }^{\circledR}$ ), in a quiet room lighted from 6 AM to 6 PM.

Three days before experiments animals were caged singly.

1. Production of alloxan diabetes: after a $24 \mathrm{~h}$ fast ether anesthetized rats of $150-170 \mathrm{~g} \mathrm{b.w}$. received i.v. $80 \mathrm{mg} / \mathrm{kg} \mathrm{b.w.} \mathrm{alloxan,} \mathrm{freshly} \mathrm{dissolved} \mathrm{to} 20 \mathrm{mg} /$ $\mathrm{ml}$ in $\mathrm{NaCl} 0.9 \% .48 \mathrm{~h}$ later the animals were checked for diabetes (glucosuria and ketosuria) and all nondiabetics excluded from further studies. For three weeks they received Depot-Insulin-Hoechst 2.4 I.U./ $100 \mathrm{~g}$ in a single s.c. injection at 5 PM. During this time animals gained weight as fast as control animals of the same litter.

2. Time schedule for blood withdrawal in different experiments: a) plasma corticosterone determination: cages were taken to a separate room, blood was withdrawn by heart puncture under very short ether anesthesia, not exceeding $3 \mathrm{~min}$. The whole procedure

\footnotetext{
* supported by the Deutsche Forschungsgemeinschaft
}

from touching the cage in the store room until completion of blood withdrawal was completed within $2 \mathrm{~min}$; within this time there was no stress response in corticosterone levels detected. b) acid-base status of the blood: just after procedure a) $50 \mathrm{mg} / \mathrm{kg} \mathrm{b.w.} \mathrm{Nem-}$ butal was given i.p., $15 \mathrm{~min}$ later $5 \mathrm{ml}$ blood were taken from the abdominal aorta under strict anaerobic conditions. All determinations of $\mathrm{pH}, \mathrm{pCO}_{2}, \mathrm{pO}_{2}$ were completed within $1 \mathrm{~h}$.

3. Adrenalectomy and hypophysectomy of alloxan diabetic rats were performed 16 to $20 \mathrm{~h}$ after the last insulin injection. Adrenalectomized rats were given $0.9 \% \mathrm{NaCl}$ solution to drink.

Methods: $\mathrm{pH}$ - Astrup-micro-equipment; $\mathrm{pO}_{2}$ and $\mathrm{pCO}_{2}$-Eschweiler-Combi-Analysator ; bicarbonate calculated [5]; $\beta$-hydroxybutyrate and acetoacetate [6], modified [7]; FFA [8]; plasma corticosterone [9].

\section{Results}

I. Plasma corticosterone levels during the development of ketoacidosis after withholding insulin in alloxan diabetic rats:

Alloxan diabetic rats receiving one daily insulin injection at 5 PM have an undisturbed circadian rhythm (unpublished data). By definition, $24 \mathrm{~h}$ after the insulin injection are called "under insulin therapy". When this insulin injection is withheld, the plasma corticosterone level follows the normal late afternoon peak of normal and insulin treated alloxan diabetic rats. However the following morning level is significantly elevated to $9.1 \pm 1.9 \mu \mathrm{g} / 100 \mathrm{ml}^{\mathbf{1}}(\mathrm{n}=19)$ in comparison to $4.2 \pm 0.9 \mu \mathrm{g} / 100 \mathrm{ml}(\mathrm{n}=19)$ under insulin therapy $(p<0.01)$, although the rhythm is not yet totally abolished. $24 \mathrm{~h}$ later the rhythm is totally abolished. and a few hours later plasma corticosterone rises to

1 mean \pm S.E.M., (n) 
about $50 \pm 6 \mu \mathrm{g} / 100 \mathrm{ml}(\mathrm{n}=15)$, i.e. $76 \mathrm{~h}$ after the last insulin injection (Fig. 1).

II. Development of ketoacidosis after withholding insulin treatment:

Under insulin therapy blood glucose and ketonebody concentration are not in the normal range. After withholding insulin glucose rises to about $400 \mathrm{mg} /$
When $\mathrm{pH}$ is plotted against plasma corticosterone a highly significant correlation is found:

$\mathrm{r}-0.681(p<0.005)$. Blood bicarbonate, plasma ketone body and FFA concentrations are also correlated with the plasma corticosterone concentration.

III. Effect of adrenalectomy, hypophysectomy or ACTH stimulation on ketoacidosis after insulin with-

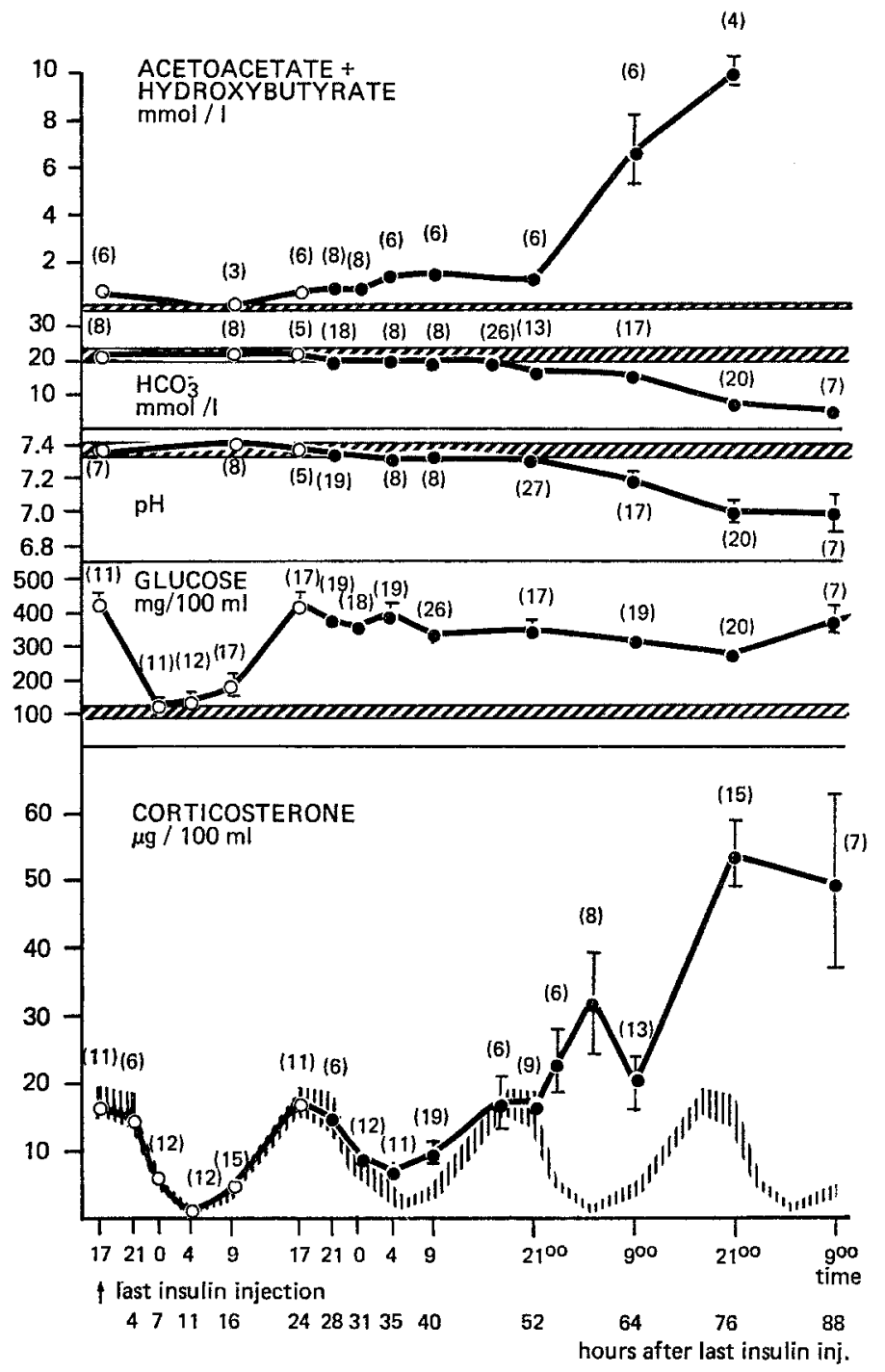

Fig. 1. Pattern of plasma corticosterone, bicarbonate, ketonebodies, blood glucose, and pH after withholding insulin therapy. Open circles: $0-24 \mathrm{~h}$ after the last insulin injection. Closed circles: later than $24 \mathrm{~h}$ after the last insulin injection. Hatched area: normal range. Mean \pm S.E.M. (n)

$100 \mathrm{ml}$ and remains in this range throughout the experiment. The ketone body concentration is increased to about $1.5 \mathrm{mmol} / \mathrm{l}$ during $52 \mathrm{~h}$ after the last insulin injection, then rises to $10 \mathrm{mmol} / \mathrm{l}$. This pattern is reflected by a steady decrease in bicarbonate concentration and finally by $\mathrm{pH}$. Both parameters are found significantly below the normal range at 52 and $64 \mathrm{~h}$ after the last insulin injection (Fig.1). drawal: As shown in Fig. 2 insulin withdrawal in adrenalectomized, alloxan-diabetic rats did not result in the development of severe ketoacidosis, although ketone bodies and FFA are significantly increased when compared to normal animals. Blood glucose is in the same range as in diabetic rats with intact adrenals. The same results are found in hypophysectomized diabetic rats (Fig. 3). When $\mathrm{ACTH}_{1-24}$ (Synacthen Depot ${ }^{\circledR}$ ) is 
given i.m. every $10 \mathrm{~h}$, in a dose of $50 \mu \mathrm{g} /$ animal to alloxan diabetic rats a continuous maximal elevated level of corticosterone results (above $35 \mu \mathrm{g} / 100 \mathrm{ml}$ ). The adrenocortical stimulation results in an acceleration of the development of ketoacidosis depending on the time interval between the last insulin injection and the experiment. So it takes 22 or $10 \mathrm{~h}$ of adrenocortical stimulation of animals 27 or $40 \mathrm{~h}$ after the last insulin injection to produce a severe ketoacidosis, comparable to alloxan diabetic rats $72 \mathrm{~h}$ after the last insulin injection, when kept under resting conditions (Fig. 3).

Saline injections, instead of ACTH, are without effect, which excludes lipolytic effects of catecholamines released by the stress of i.m. injection.

In insulin deficient rats $-40 \mathrm{~h}$ after the last insulin injection - FFA levels are significantly decreased after $10 \mathrm{~h}$ of ACTH stimulation when compared to unstimulated animals (Fig. 3). This may be due to almost complete depletion of fat depots after adrenocortical stimulation, which was confirmed by autopsy.

\section{Discussion}

The steady increase of plasma corticosterone during the development of ketoacidosis after withholding insulin therapy in the alloxan diabetic rat may be the result of different regulatory mechanisms: increased adrenocortical sensitivity to endogenous $\mathrm{ACTH}$, disturbances of the feedback mechanism, and of the cireadian rhythm of plasma corticosterone (unpublished

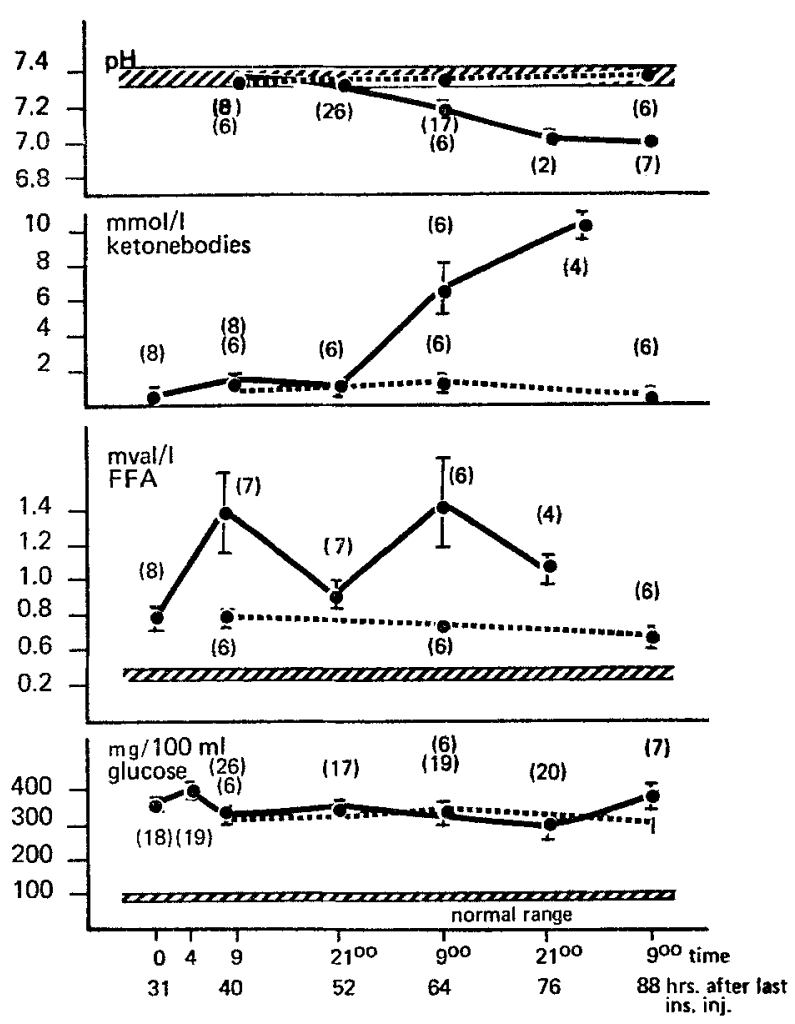

Fig. 2. Pattern of blood glucose, $\mathrm{pH}$, plasma FFA, and ketonebodies after withholding insulin therapy in diabetic rats with intact adrenocortical system (-0) and after adrenalectomy (-..). Mean \pm S.E.M., (n)

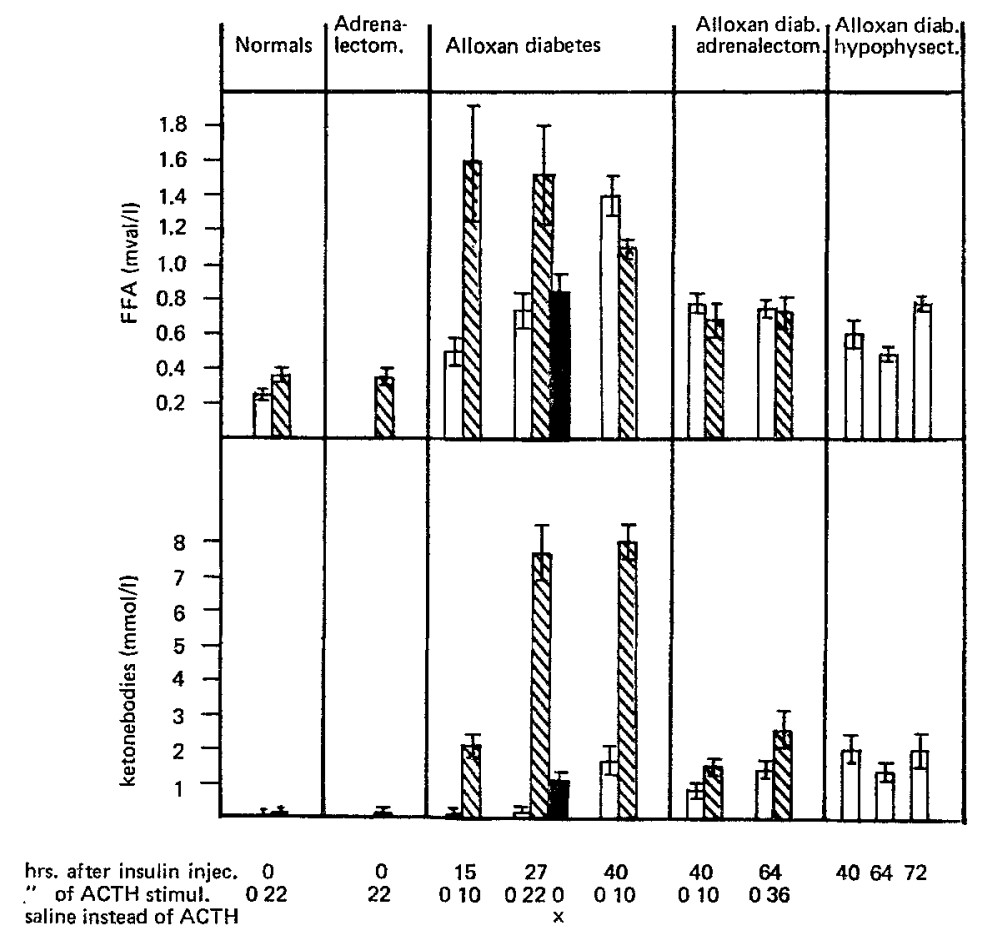

Fig. 3. FFA and ketonebodies under exogenous ACTH stimulation after withholding insulin therapy. Open bars: without ACTH; hatched bars: with ACTH; filled bars: saline injection. Mean \pm S. E.M., $n=5-7$ animals 
data), as well as to reduced metabolic clearance of corticosterone in severe insulin deficiency [10].

If the animals are kept under resting conditions, the inerease in plasma corticosterone does exactly reflect the pattern of metabolic parameters of diabetic ketoacidosis and is not a preceding event.

No conclusion on a causal relationship can be drawn from the reported correlation between plasma corticosterone and FFA, ketonebodies, bicarbonate or $\mathrm{pH}$, since other hormones interfering with fat metabolism are reported to be increased in diabetic ketoacidosis, such as growth hormone [11] and catecholamines [12].

A participation of the adrenocortical system in the development of ketoacidosis in insulin deficient animals, however, can be deduced from the experiments excluding or stimulating the adrenocortical system (Fig. 2, 3).

Our results are in good agreement with those of others $[13,14]$.

Adrenalectomy prevents the development of severe ketoacidosis (Fig. 2). Under these experimental conditions pituitary hormones are still present and catecholamines are not excluded, since the sympathetic innervation of the fat tissue may be still intact. Hypophysectomy also prevents severe ketoacidosis; in these experiments catecholamines coming from the adrenal medulla are not excluded. On the other hand, exclusive stimulation of the adrenal cortex, resulting in maximal plasma corticosterone levels, accelerates the development of severe ketoacidosis (Fig. 3). So the fact that the insulin deficient rat responds to a stress signal with significantly higher plasma corticosterone levels (Table 1) in early insulin deficiency (before severe ketosis has developed), could be of metabolic consequence.

Table 1. Plasma conticosterone $(\mu \mathrm{g} / 100 \mathrm{ml}) 15 \mathrm{~min}$. after stress application.

\begin{tabular}{|c|c|c|c|}
\hline \multirow[b]{2}{*}{ stress } & \multirow[b]{2}{*}{ controls } & \multicolumn{2}{|c|}{ Alloxan diabetic rats } \\
\hline & & $\begin{array}{l}16 \mathrm{~h} \text { after tho } \\
\text { last insulin } \\
\text { inject. }\end{array}$ & $\begin{array}{l}40 \mathrm{~h} \text { after } \\
\text { last insulin } \\
\text { inject. }\end{array}$ \\
\hline $\begin{array}{l}\text { handling + } \\
\text { barbiturate } \\
\text { i.p. }\end{array}$ & $\begin{array}{l}12.0 \pm 1.7 \\
(\mathbf{1 3})\end{array}$ & $\begin{array}{l}15.5 \pm 2.7 \\
(10)\end{array}$ & $\begin{array}{l}27.0 \pm 2.2 \\
(11) \\
p<0.01\end{array}$ \\
\hline $\begin{array}{l}\mathrm{LVPa}^{\mathrm{a}}(30 \mathrm{mU}, \\
\text { i. v.) }\end{array}$ & $\begin{array}{l}31.2 \pm 1.4 \\
(6)\end{array}$ & $\begin{array}{l}34.3 \pm 3.7 \\
(6)\end{array}$ & $\begin{array}{l}48.6 \pm 3.5 \\
(5) \\
p<0.025\end{array}$ \\
\hline scald, $80^{\circ} \mathrm{C}$ & - & $\begin{array}{l}37.6 \pm 3.2 \\
(6)\end{array}$ & $\begin{array}{l}57.3 \pm 3.6 \\
(6) \\
p<0.01\end{array}$ \\
\hline 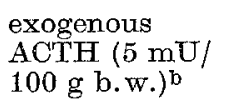 & $\begin{array}{l}27.0 \pm 0.9 \\
(6)\end{array}$ & $\begin{array}{l}30.7 \pm 2.4 \\
(6)\end{array}$ & $\begin{array}{l}48.6 \pm 4.1 \\
(6) \\
p<0.01\end{array}$ \\
\hline
\end{tabular}

Mean \pm S.E.M., (n)

a Lysine Vasopressin

$\mathrm{b}$ Endogenous ACTH release is blocked by dexamethasone
Since growth hormone [11] and catecholamine levels [12] are increased in acute diabetes and have lipolytic activities [14], the development of ketosis in insulin deficiency may be a consequence of multihormonal interference, where lipolytic hormones may stimulate lipolysis in adipose tissue while glucocorticoids may limit the reesterification of FFA by suppressing the metabolism of glucose [15].

\section{References}

1. Klein, R., Weigend, F.A., Junes, M., Greenman, L.: Corticoids in serum of children with treated diabetes mellitus. Pediatries 17, $214-220$ (1956)

2. Gerich, J.E., Martin, M.M., Recant, L.: Clinical and metabolic characteristics of hyperosmolar nonketotic coma. Diabetes 20, 228 -- 238 (1971)

3. von der Nahmer, D., Miss, H.-D., Jahnke, K.: Die Funktion der Nebennierenrinde im diabetischen Koma. Klin. Wschr. 49, 578-583 (1971)

4. Wieland, O.: Ketogenesis and its regulation. Advane. Metab. Disord. 3, 1-47 (1968)

5. Davenport, H.W.: The ABC of acid-base chemistry, 4. Edition. The University of Chicago Press 1958

6. Williamson, D.H., Mellanby, J., Krebs, H.A.: Enzymatic determination of $\mathrm{D}$-(-)-3-hydroxybutyric and acetoacetic acid in blood. Biochem. J. 82, 90-95 (1962)

7. Stein, G., Bässler, K.H.: Mikromethode zur enzymatischen Bestimmung von Acetessigsäure und D-(-)- $\beta$-Hydroxybuttersäure in Blut und Geweben. Z. klin. Chem. 6, 27-30 (1968)

8. Duncombe, W.G.: The colorimetric micro-determination of non-esterified fatty acids in plasma. Clin. chim. Acta 9, 122-125 (1964)

9. Glick, D.D., von Redlich, D., Levine, S.: Fluorometric determination of corticosterone and cortisol in $0.02-0.05$ milliliters of plasma or submilligram samples of adrenal tissue. Endocrinology 74, 653-655 (1964)

10. Garren, L.D., Cahill, G.F.Jr.: Effect of experimental diabetes on steroid metabolism. I. The effect of diabetes on $\Delta^{4}-3$-ketosteroid reductase activity. J. biol. Chem. 238, 2923-2925 (1963)

11. Johansen, K., Hansen, Aa.P.: Diurnal serum growth hormone in poorly and well-controlled juvenile diabetics. Diabetes 20, 239-245 (1971)

12. Christensen, N.J.: Plasma catecholamines in juvenile diabetics. Scand. J. clin. Lab. Invest. 27, 227-231 (1971)

13. Scow, R.O., Chernick, S.S., Guarco, B.A. : Ketogenic action of pituitary and adrenal hormones in pancreatectomized rats. Diabetes 8, 132-141 (1959)

14. Scow, R.O., Chernick, S.S.: Mobilization, transport and utilization of free fatty acids. Compr. Biochem. 18, $19-49(1970)$

15. Chernick, S.S., Clark, C.M., Gardiner, R.J., Scow, R.O.: Role of lipolytic and glucocorticoid hormones in the development of diabetic ketosis. Diabetes 21, $946-954(1972)$
Dr. M. L'age
Klinikum Steglitz
der Freien Universität Berlin
Medizinische Klinik
1 Berlin 45
Kindenburgdamm 30
Federal Republik of Germany 